Article

\title{
Identification of the Chemical Constituents in Aqueous Extract of Zhi-Qiao and Evaluation of Its Antidepressant Effect
}

\author{
Ming Wu ${ }^{1,2, \dagger}$, Hongwu Zhang ${ }^{2, \dagger}$, Chao Zhou ${ }^{2}$, Hongmei Jia ${ }^{2}$, Zhuo Ma ${ }^{1, *}$ and \\ Zhongmei Zou ${ }^{2, *}$
}

1 Department of Food and Pharmaceutical, Hubei University of Technology, Wuhan 430068, China; E-Mail: hbwuming@163.com

2 Institute of Medicinal Plant Development, Chinese Academy of Medical Sciences and Peking Union Medical College, Beijing 100193, China; E-Mails: 18101318775@163.com (H.Z.); smilezhouchao@163.com (C.Z.); jia090909@126.com (H.J.)

$\dagger$ These authors contributed equally to this work.

* Authors to whom correspondence should be addressed; E-Mails: mazhuo@mail.hbut.edu.cn (Z.M.); zmzou@implad.ac.cn (Z.Z.); Tel.: +86-1397-1371-028 (Z.M.); Tel./Fax: +86-10-5783-3290 (Z.Z.).

Academic Editor: Thomas J. Schmidt

Received: 30 January 2015 / Accepted: 14 April 2015 / Published: 16 April 2015

\begin{abstract}
The immature fruit of Citrus aurantium L. (Zhi-Qiao, ZQ) has been used as a traditional medicine in China. Our previous study has shown that ZQ decoction may contribute to the antidepressant-like action of Chaihu-Shu-Gan-San. However, there are no reports on the chemical constituents of ZQ aqueous extract or its anti-depression effects. Firstly, this research reported the on-line identification of the chemical constituents in the aqueous extract of ZQ by coupling ultra-performance liquid chromatography/time-of-flight mass spectrometry (UPLC-Q-TOF/MS). A total of 31 chemical constituents were identified in ZQ aqueous extract, including one tannic acid, five flavones, 13 flavanones, one limonoid, three coumarins, three cyclic peptides, and five polymethoxylated flavonoids. The antidepressant effect of ZQ aqueous extract was evaluated in vivo and the results indicated that the mice immobility time during the forced swimming test and the tail suspension test were significantly reduced with ZQ treatment. MTT assays showed both ZQ aqueous extract and its major constituents (naringin, hesperidin, neohesperidin, and nobiletin) had neuroprotective effect on corticosterone-induced neurotoxicity in PC12 cells. The in vivo and in vitro results suggest that $\mathrm{ZQ}$ has an antidepressant effect.
\end{abstract}


Keywords: Citrus aurantium; UPLC-Q-TOF/MS; antidepressant; PC12 cells

\section{Introduction}

Citrus aurantium L. (bitter orange) has been widely cultivated in tropics and subtropics. The extract of its immature fruit or peel is added to many weight loss formulas in dietary supplements. The immature fruit of $C$. aurantium (Zhi-Qiao, ZQ) has also been used as a traditional medicine in China for treating the stagnation of dyspepsia, improving gastrointestinal function, and reducing chest pain $[1,2]$.

The chemical composition of ZQ includes flavonoids (naringin, hesperidin, neohesperidin) [3], alkaloids (synephrine) [4], and coumarins (meranzin, auraptene) [5]. With the development of the LC-MS instrument, it has become more popular for direct identification of multiple components in a complicated matrix [6]. Ultra-performance liquid chromatography/time-of-flight mass spectrometry [7] and atmospheric pressure chemical ionization mass spectrometry [8] have been applied in characterization of polymethoxylated flavonoids (PMFs) in the ethyl acetate extract of ZQ. Unfortunately, these works lack of identification of accurate structures. Recently, Chen et al. [9] investigated the antioxidants in the methanol extract of ZQ and identified 25 flavones with a HPLC-DAD-MS method.

Pharmacological studies have revealed that ZQ has diverse bioactivities, including anti-tumor [10], anti-oxidation [11], anti-virus [12], anti-inflammation [13], anti-bacterial [14], anti-allergic [15], and effects on mammalian metabolism [16]. The alcohol extract of ZQ could improve the sucrose preference test and reduce the forced swimming time on the chronic unpredicted mild stress (CUMS) model of depression in rats [17]. ZQ is one of the key herbs in Chaihu-Shu-Gan-San (CSGS), a traditional Chinese medicines (TCMs) formula for treatment of depression clinically in China [18]. During our research on antidepressant effect of CSGS, we found that CSGS lost some of the important regulatory action on the disturbance of metabolic pathways related to depression, when one of the herbs ZQ was removed from CSGS [19]. These findings encouraged us to explore the contributions of ZQ to the antidepressant-like action of CSGS.

Traditionally, the most commonly used form of TCMs is a decoction. However, there are no reports on the chemical constituents of ZQ decoction or its anti-depression effect. Consequently, in this paper the on-line identification of the multiple components in the aqueous extract of ZQ was performed using an efficient and sensitive UPLC-Q-TOF/MS method. Then, the antidepressant effects of ZQ aqueous extract were evaluated using a forced swimming test and tail suspension test. Further, the neuroprotective effects of ZQ aqueous extract and its main chemical constituents (naringin, hesperidin, neohesperidin, and nobiletin) were determined on corticosterone-induced neurotoxicity in PC12 cells.

\section{Results and Discussion}

\subsection{Optimization of LC and MS Conditions}

In order to cover the overall constituents of $Z Q$ aqueous extract with good resolution in a short analysis, UPLC parameters, including column temperature $\left(30{ }^{\circ} \mathrm{C}, 35^{\circ} \mathrm{C}\right.$, and $\left.40{ }^{\circ} \mathrm{C}\right)$, mobile phases systems (methanol-aqueous, acetonitrile-aqueous, methanol-aqueous with $0.1 \%$ formic acid, and 
acetonitrile-aqueous with $0.1 \%$ formic acid), and gradient program were examined. Subsequently, the MS conditions including the desolvation gas flow $(600,800$, and 1,200 L/H), capillary voltage $(2.5$, 3.0 , and $3.5 \mathrm{kV}$ in positive ion mode; $2.0,2.5$, and $3.0 \mathrm{kV}$ in negative ion mode), and the cone voltage $(30,35$, and $40 \mathrm{~V})$ were also optimized. The total peak area was taken as criteria for optimization. As a result, the optimum conditions were determined as described in Section 3.3.

\subsection{Identification of Chemical Constituents in ZQ Aqueous Extract}

The reference substances and ZQ sample were analyzed by using the optimized UPLC-Q-TOF/MS method. The base peak intensity (BPI) chromatograms of ZQ sample in positive and negative ESI modes are shown in Figure 1. For most of the constituents, $[\mathrm{M}-\mathrm{H}]^{-},[\mathrm{M}+\mathrm{H}]^{+}$and/or $[\mathrm{M}+\mathrm{Na}]^{+}$adduct ions were observed. Due to the use of formic acid in mobile phase, the $[\mathrm{M}+46-\mathrm{H}]^{-}$fragment ions corresponding to $[\mathrm{M}+\mathrm{HCOOH}-\mathrm{H}]^{-}$were also observed in negative ion mode. The results provided valuable information for confirming accurate molecular weights and the composition of the constituents. Based on the retention behaviors, accurate molecular weight and $\mathrm{MS}^{\mathrm{n}}$ fragment data, 31 compounds from the ZQ aqueous extract were tentatively identified (Figure 2) by comparison with reference substances and literature data (Table 1). The identified compounds can be classified into seven classes including one tannic acid (peak 1), five flavones (peaks 2, 3, 13, 17, 20), 13 flavanones (peaks 4, 5, 6, 7, 9, 10,11, 14, 15, 18, 21, 22, 23), one limonoid (peak 8), three coumarins (peak 12, 16,25 ), three cyclic peptides (peak 19, 26, 29), and five polymethoxylated flavonoids (peaks 24, 27, $28,30,31)$.

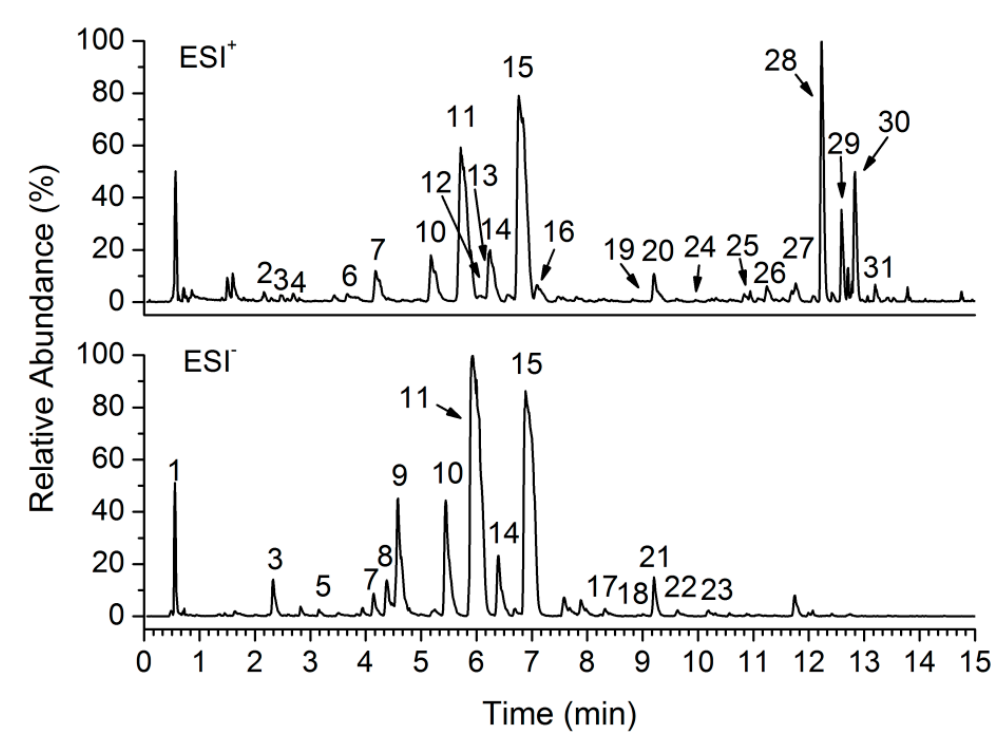

Figure 1. Typical UPLC-Q-TOF/MS base peak intensity (BPI) chromatograms of ZQ aqueous extract in positive and negative ion modes. 
Table 1. Identification of the chemical constituents in ZQ aqueous extract by UPLC-Q-TOF/MS analysis.

\begin{tabular}{|c|c|c|c|c|c|c|c|}
\hline \multirow{2}{*}{ Peak No. } & \multirow{2}{*}{ Identification } & \multirow{2}{*}{$\mathbf{R t}^{\mathrm{c}}$ (min) } & \multirow{2}{*}{ Formula } & \multicolumn{2}{|c|}{ Positive Ion Mode of ESI-MS $(\mathrm{m} / \mathrm{z})$} & \multicolumn{2}{|c|}{ Negative Ion Mode of ESI-MS $(\mathrm{m} / \mathrm{z})$} \\
\hline & & & & Quasi-molecular ion & MS $^{2}$ ions & Quasi-molecular ion & MS $^{2}$ ions \\
\hline 1 & 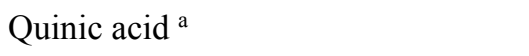 & 0.55 & $\mathrm{C}_{7} \mathrm{H}_{12} \mathrm{O}_{6}$ & - & - & $191.0558[\mathrm{M}-\mathrm{H}]^{-}$ & 165.0363 \\
\hline 2 & 6,8-Di-glucopyranocylapigenin ${ }^{b}$ & 2.16 & $\mathrm{C}_{27} \mathrm{H}_{30} \mathrm{O}_{15}$ & $595.1670[\mathrm{M}+\mathrm{H}]^{+}$ & $\begin{array}{l}577.1560 \\
457.1149\end{array}$ & - & - \\
\hline 3 & Isovitexin ${ }^{b}$ & 2.39 & $\mathrm{C}_{21} \mathrm{H}_{20} \mathrm{O}_{10}$ & $433.1233[\mathrm{M}+\mathrm{H}]^{+}$ & $\begin{array}{l}379.0893 \\
367.0936 \\
313.1040 \\
625.1794\end{array}$ & $431.0986[\mathrm{M}-\mathrm{H}]^{-}$ & 353.1286 \\
\hline 4 & Glucosyl-naringin ${ }^{\mathrm{b}}$ & 2.68 & $\mathrm{C}_{33} \mathrm{H}_{42} \mathrm{O}_{19}$ & $765.2200[\mathrm{M}+\mathrm{Na}]^{+}$ & $\begin{array}{l}581.1855 \\
539.1867\end{array}$ & - & - \\
\hline 5 & Naringenin-7-O-triglycoside ${ }^{b}$ & 3.15 & $\mathrm{C}_{33} \mathrm{H}_{42} \mathrm{O}_{19}$ & - & $\begin{array}{l}- \\
435.1441\end{array}$ & $741.2241[\mathrm{M}-\mathrm{H}]^{-}$ & 433.1134 \\
\hline 6 & Naringenin-7- $O$-sophorose ${ }^{\mathrm{b}}$ & 3.71 & $\mathrm{C}_{27} \mathrm{H}_{32} \mathrm{O}_{15}$ & $597.1827[\mathrm{M}+\mathrm{H}]^{+}$ & $\begin{array}{l}417.1241 \\
199.1124\end{array}$ & - & - \\
\hline 7 & Eriocitrin $^{\mathrm{b}}$ & 4.18 & $\mathrm{C}_{27} \mathrm{H}_{32} \mathrm{O}_{15}$ & $597.1796[\mathrm{M}+\mathrm{H}]^{+}$ & $\begin{array}{l}289.0714 \\
179.0316 \\
163.0404\end{array}$ & $595.1669[\mathrm{M}-\mathrm{H}]^{-}$ & 287.0620 \\
\hline 8 & Ichangin-4-O- $\beta$-D-glucopyranoside ${ }^{b}$ & 4.38 & $\mathrm{C}_{32} \mathrm{H}_{42} \mathrm{O}_{14}$ & - & - & $649.2505[\mathrm{M}-\mathrm{H}]^{-}$ & $\begin{array}{l}605.2636 \\
443.2061\end{array}$ \\
\hline 9 & Neoeriocitrin ${ }^{b}$ & 4.59 & $\mathrm{C}_{27} \mathrm{H}_{32} \mathrm{O}_{15}$ & - & - & $595.1658[\mathrm{M}-\mathrm{H}]^{-}$ & 459.1152 \\
\hline 10 & Narirutin $^{a}$ & 5.19 & $\mathrm{C}_{27} \mathrm{H}_{32} \mathrm{O}_{14}$ & $603.1685[\mathrm{M}+\mathrm{Na}]^{+}$ & $\begin{array}{l}581.1850 \\
503.1530 \\
435.1188 \\
273.0711\end{array}$ & $579.1719[\mathrm{M}-\mathrm{H}]^{-}$ & 271.0622 \\
\hline
\end{tabular}


Table 1. Cont.

\begin{tabular}{|c|c|c|c|c|c|c|c|}
\hline \multirow{2}{*}{ Peak No. } & \multirow{2}{*}{ Identification } & \multirow{2}{*}{$\mathbf{R t}^{c}$ (min) } & \multirow{2}{*}{ Formula } & \multicolumn{2}{|c|}{ Positive Ion Mode of ESI-MS $(\mathrm{m} / \mathrm{z})$} & \multicolumn{2}{|c|}{ Negative Ion Mode of ESI-MS $(\mathrm{m} / \mathrm{z})$} \\
\hline & & & & Quasi-molecular ion & MS $^{2}$ ions & Quasi-molecular ion & MS $^{2}$ ions \\
\hline 11 & Naringin $^{a}$ & 5.71 & $\mathrm{C}_{27} \mathrm{H}_{32} \mathrm{O}_{14}$ & $603.1693[\mathrm{M}+\mathrm{Na}]^{+}$ & $\begin{array}{l}581.1850 \\
503.1530 \\
435.1188 \\
273.0711\end{array}$ & $579.1724[\mathrm{M}-\mathrm{H}]^{-}$ & $\begin{array}{l}\text { 459.1138; } \\
271.0649\end{array}$ \\
\hline 12 & Meranzin- $O$-glucoside ${ }^{b}$ & 5.84 & $\mathrm{C}_{21} \mathrm{H}_{28} \mathrm{O}_{10}$ & $463.1578[\mathrm{M}+\mathrm{Na}]^{+}$ & $\begin{array}{l}419.1343 \\
503.1538\end{array}$ & - & - \\
\hline 13 & Rhoifolin $^{\mathrm{b}}$ & 5.87 & $\mathrm{C}_{27} \mathrm{H}_{30} \mathrm{O}_{14}$ & $579.1698[\mathrm{M}+\mathrm{H}]^{+}$ & $\begin{array}{l}355.1575 \\
273.0760\end{array}$ & - & - \\
\hline 14 & Hesperidin ${ }^{\text {a }}$ & 6.25 & $\mathrm{C}_{28} \mathrm{H}_{34} \mathrm{O}_{15}$ & $633.1792[\mathrm{M}+\mathrm{Na}]^{+}$ & $\begin{array}{l}449.1434 \\
413.1336 \\
303.0869\end{array}$ & $609.1833[\mathrm{M}-\mathrm{H}]^{-}$ & $\begin{array}{l}301.0723 \\
286.0500 \\
151.0063\end{array}$ \\
\hline 15 & Neohesperidin $^{\text {a }}$ & 6.81 & $\mathrm{C}_{28} \mathrm{H}_{34} \mathrm{O}_{15}$ & $633.1794[\mathrm{M}+\mathrm{Na}]^{+}$ & $\begin{array}{l}449.1434 \\
413.1336 \\
303.0873\end{array}$ & $609.1816[\mathrm{M}-\mathrm{H}]^{-}$ & $\begin{array}{l}489.1423 \\
343.0804 \\
301.0660\end{array}$ \\
\hline 16 & Meranzin ${ }^{\mathrm{b}}$ & 7.09 & $\mathrm{C}_{15} \mathrm{H}_{16} \mathrm{O}_{4}$ & $261.1139[\mathrm{M}+\mathrm{H}]^{+}$ & 189.0554 & - & - \\
\hline 17 & 6,8-Di-glucopyranocyldiosmetin ${ }^{\mathrm{b}}$ & 8.25 & $\mathrm{C}_{28} \mathrm{H}_{32} \mathrm{O}_{16}$ & - & - & $623.1945[\mathrm{M}-\mathrm{H}]^{-}$ & 503.1146 \\
\hline 18 & Neoponcirin ${ }^{\mathrm{b}}$ & 8.94 & $\mathrm{C}_{28} \mathrm{H}_{34} \mathrm{O}_{14}$ & - & - & $593.1899[\mathrm{M}-\mathrm{H}]^{-}$ & 285.0778 \\
\hline 19 & Cyclo(-Gly-Leu-Val-Leu-Pro-Ser-) ${ }^{\text {b }}$ & 9.20 & $\mathrm{C}_{27} \mathrm{H}_{46} \mathrm{~N}_{6} \mathrm{O}_{7}$ & $589.3329[\mathrm{M}+\mathrm{Na}]^{+}$ & $\begin{array}{l}567.3504 \\
454.2654\end{array}$ & - & - \\
\hline 20 & Kaempferol $^{\mathrm{b}}$ & 9.25 & $\mathrm{C}_{15} \mathrm{H}_{10} \mathrm{O}_{6}$ & $287.0924[\mathrm{M}+\mathrm{H}]^{+}$ & 239.2353 & - & - \\
\hline 21 & Fumotonaringin ${ }^{b}$ & 9.29 & $\mathrm{C}_{28} \mathrm{H}_{34} \mathrm{O}_{14}$ & - & - & $593.1853[\mathrm{M}-\mathrm{H}]^{-}$ & 285.0767 \\
\hline 22 & Naringenin ${ }^{b}$ & 9.63 & $\mathrm{C}_{15} \mathrm{H}_{12} \mathrm{O}_{5}$ & - & - & $271.0613[\mathrm{M}-\mathrm{H}]^{-}$ & 151.0041 \\
\hline 23 & Hesperitin ${ }^{b}$ & 10.19 & $\mathrm{C}_{16} \mathrm{H}_{14} \mathrm{O}_{6}$ & - & - & $301.0760[\mathrm{M}-\mathrm{H}]^{-}$ & $\begin{array}{l}286.0501 \\
242.0572\end{array}$ \\
\hline
\end{tabular}


Table 1. Cont.

\begin{tabular}{|c|c|c|c|c|c|c|c|}
\hline \multirow{2}{*}{ Peak No. } & \multirow{2}{*}{ Identification } & \multirow{2}{*}{$\operatorname{Rt}^{c}(\min )$} & \multirow{2}{*}{ Formula } & \multicolumn{2}{|c|}{ Positive Ion Mode of ESI-MS $(\mathrm{m} / \mathrm{z})$} & \multicolumn{2}{|c|}{ Negative Ion Mode of ESI-MS $(\mathrm{m} / \mathrm{z})$} \\
\hline & & & & Quasi-molecular ion & MS $^{2}$ ions & Quasi-molecular ion & MS $^{2}$ ions \\
\hline 24 & 3-Methoxynobiletin ${ }^{a}$ & 10.24 & $\mathrm{C}_{22} \mathrm{H}_{24} \mathrm{O}_{9}$ & $433.1486[\mathrm{M}+\mathrm{H}]^{+}$ & $\begin{array}{l}\text { 403.1021; } \\
373.0571\end{array}$ & - & - \\
\hline 25 & Epoxybergamottin ${ }^{\mathrm{b}}$ & 10.85 & $\mathrm{C}_{21} \mathrm{H}_{22} \mathrm{O}_{5}$ & $355.1518[\mathrm{M}+\mathrm{H}]^{+}$ & 344.0939 & - & - \\
\hline 26 & Citrusin $\mathrm{I}^{\mathrm{b}}$ & 10.94 & $\mathrm{C}_{34} \mathrm{H}_{53} \mathrm{~N}_{7} \mathrm{O}_{9}$ & $726.3782[\mathrm{M}+\mathrm{Na}]^{+}$ & $\begin{array}{l}704.3984 \\
591.3105\end{array}$ & - & - \\
\hline 27 & Isosinensetin ${ }^{b}$ & 11.56 & $\mathrm{C}_{20} \mathrm{H}_{20} \mathrm{O}_{7}$ & $373.1264[\mathrm{M}+\mathrm{H}]^{+}$ & $\begin{array}{l}358.1040 \\
343.1270\end{array}$ & - & - \\
\hline 28 & Nobiletin $^{\text {a }}$ & 12.23 & $\mathrm{C}_{21} \mathrm{H}_{22} \mathrm{O}_{8}$ & $403.1397[\mathrm{M}+\mathrm{H}]^{+}$ & $\begin{array}{l}383.1766 \\
239.1505\end{array}$ & - & - \\
\hline 29 & Cyclo(-Gly-Gly-Leu-Leu-Leu-Pro-Pro-Phe-) ${ }^{b}$ & 12.78 & $\mathrm{C}_{41} \mathrm{H}_{62} \mathrm{~N}_{8} \mathrm{O}_{8}$ & $817.4586[\mathrm{M}+\mathrm{Na}]^{+}$ & $\begin{array}{l}795.4759 \\
682.3929 \\
399.2105\end{array}$ & - & - \\
\hline 30 & Tangeretin $^{a}$ & 12.82 & $\mathrm{C}_{20} \mathrm{H}_{20} \mathrm{O}_{7}$ & $373.1288[\mathrm{M}+\mathrm{H}]^{+}$ & $\begin{array}{l}358.1063 \\
343.0814\end{array}$ & - & - \\
\hline 31 & 7-Hydroxyl-4',3,5,6,8-pentamethoxy-flavone ${ }^{b}$ & 13.20 & $\mathrm{C}_{20} \mathrm{H}_{20} \mathrm{O}_{8}$ & $389.1240[\mathrm{M}+\mathrm{H}]^{+}$ & $\begin{array}{l}374.1106 \\
359.0764 ; \\
197.0739\end{array}$ & - & - \\
\hline
\end{tabular}

${ }^{\mathrm{a}}$ Structurally confirmed by comparison with reference chemicals; ${ }^{\mathrm{b}}$ Structure assignment tentative, based on MS and literature data; ${ }^{\mathrm{c}} \mathrm{Rt}$ : retention time. 
<smiles>O=C(O)C1(O)CC(O)C(O)C(O)C1</smiles>

$1^{a}$<smiles>[R]c1ccc(-c2cc(=O)c3c(O)c(Cl)c(O)c([R3])c3o2)cc1[R]</smiles>

$2^{\text {b }} \mathrm{R}_{1}=\mathrm{H}, \mathrm{R}_{2}=\mathrm{OH}, \mathrm{R}_{3}=\mathrm{Glu}$ $3^{\text {b }} \mathrm{R}_{1}=\mathrm{H}, \mathrm{R}_{2}=\mathrm{OH}, \mathrm{R}_{3}=\mathrm{H}$, $17^{\mathrm{b}} \mathrm{R}_{1}=\mathrm{OH}, \mathrm{R}_{2}=\mathrm{OCH}_{3}, \mathrm{R}_{3}=\mathrm{Glu}$<smiles></smiles>

$8^{b}$<smiles>COc1ccc2ccc(=O)oc2c1CC(O)C(C)(C)OCl</smiles>

$12^{b}$<smiles>[R6]Oc1cc(O)c2c(c1)OC(c1ccc(O[R20])c([R])c1)CC2=O</smiles>

$4^{\mathrm{b}} \mathrm{R}_{1}=\mathrm{H}, \mathrm{R}_{2}=\mathrm{Glu}, \mathrm{R}_{3}=$ neohesperidose $5^{\text {b }} \mathrm{R}_{1}=\mathrm{H}, \mathrm{R}_{2}=\mathrm{H}, \mathrm{R}_{3}=$ triglycoside $6^{\text {b }} \mathrm{R}_{1}=\mathrm{H}, \mathrm{R}_{2}=\mathrm{H}, \mathrm{R}_{3}=$ sophorose $7^{\mathrm{b}} \mathrm{R}_{1}=\mathrm{OH}, \mathrm{R}_{2}=\mathrm{H}, \mathrm{R}_{3}=$ rutinose $\mathbf{9}^{\text {b }} \mathrm{R}_{1}=\mathrm{OH}, \mathrm{R}_{2}=\mathrm{H}, \mathrm{R}_{3}=$ neohesperidose $10^{\mathrm{a}} \mathrm{R}_{1}=\mathrm{H}, \mathrm{R}_{2}=\mathrm{H}, \mathrm{R}_{3}=$ rutinose $11^{\mathrm{a}} \mathrm{R}_{1}=\mathrm{H}, \mathrm{R}_{2}=\mathrm{H}, \mathrm{R}_{3}=$ neohesperidose $14^{\mathrm{a}} \mathrm{R}_{1}=\mathrm{OH}, \mathrm{R}_{2}=\mathrm{CH}_{3}, \mathrm{R}_{3}=$ rutinose $15^{\mathrm{a}} \mathrm{R}_{1}=\mathrm{OH}, \mathrm{R}_{2}=\mathrm{CH}_{3}, \mathrm{R}_{3}=$ neohesperidose $18^{\mathrm{b}} \mathrm{R}_{1}=\mathrm{H}, \mathrm{R}_{2}=\mathrm{CH}_{3}, \mathrm{R}_{3}=$ neohesperidose $21^{\mathrm{b}} \mathrm{R}_{1}=\mathrm{H}, \mathrm{R}_{2}=\mathrm{H}, \mathrm{R}_{3}=$ methylneohesperidose $2^{\text {b }} \mathrm{R}_{1}=\mathrm{H}, \mathrm{R}_{2}=\mathrm{H}, \mathrm{R}_{3}=\mathrm{H}$ $23^{\text {b }} \mathrm{R}_{1}=\mathrm{OH}, \mathrm{R}_{2}=\mathrm{CH}_{3}, \mathrm{R}_{3}=\mathrm{H}$<smiles></smiles>

$13^{b}$<smiles>COc1ccc2ccc(=O)oc2c1CC1OC1(C)C</smiles>

$16^{\mathrm{b}}$

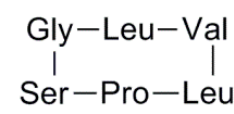

$19^{b}$<smiles>CC(=O)OCC=C(C)CCC1OC1(C)C</smiles>

$25^{\mathrm{b}}$
Gly-Gly-Leu-Leu
Phe-Pro-Pro-Leu

$29^{b}$

$$
\begin{aligned}
& 2^{\mathrm{a}} \mathrm{R}_{1}=\mathrm{OCH}_{3}, \mathrm{R}_{2}=\mathrm{OCH}_{3}, \mathrm{R}_{3}=\mathrm{OCH}_{3} \\
& \mathbf{2 7}^{\mathrm{b}} \mathrm{R}_{1}=\mathrm{OCH}_{3}, \mathrm{R}_{2}=\mathrm{H}, \mathrm{R}_{3}=\mathrm{H} \\
& \mathbf{2 8}^{\mathrm{a}} \mathrm{R}_{1}=\mathrm{OCH}_{3}, \mathrm{R}_{2}=\mathrm{OCH}_{3}, \mathrm{R}_{3}=\mathrm{H} \\
& 3^{\mathrm{a}} \mathrm{R}_{1}=\mathrm{H}, \mathrm{R}_{2}=\mathrm{OCH}_{3}, \mathrm{R}_{3}=\mathrm{H} \\
& 3^{\mathrm{b}} \mathrm{R}_{1}=\mathrm{H}, \mathrm{R}_{2}=\mathrm{OCH}_{3}, \mathrm{R}_{3}=\mathrm{OH}
\end{aligned}
$$

Figure 2. The chemical structures of compounds identified in $Z Q$ aqueous extract; ${ }^{a}$ Structurally confirmed by comparison with reference chemicals; ${ }^{\mathrm{b}}$ Structure assignment tentative, based on MS and literature data.

Here, an ion at the retention time of $6.25 \mathrm{~min}$ (peak 14) is taken as an example to illustrate the identification process. The base peak of its $[\mathrm{M}-\mathrm{H}]^{-}$at $\mathrm{m} / \mathrm{z} 609.1833$, as well as its $[\mathrm{M}+\mathrm{H}]^{+}$at $\mathrm{m} / \mathrm{z}$ 633.1792, is indicative of the molecular formula as $\mathrm{C}_{28} \mathrm{H}_{34} \mathrm{O}_{15}$. Additionally, the neutral loss of $308 \mathrm{Da}$ $\left(\mathrm{C}_{12} \mathrm{H}_{20} \mathrm{O}_{9}\right)$ from $\mathrm{C}_{28} \mathrm{H}_{33} \mathrm{O}_{15}{ }^{-}$in the $\mathrm{MS}^{\mathrm{E}}$ spectra was attributed to the characteristic ion $[\mathrm{M}-\mathrm{H}-\text { rutinose }]^{-}$fragments. Then, the loss of $15 \mathrm{Da}$ indicated the existence of "- $\mathrm{CH}_{3}$ " group. The 
fragment ion at $m / z 151.0063\left(\mathrm{C}_{7} \mathrm{H}_{3} \mathrm{O}_{4}{ }^{-}\right)$was produced from flavanone nucleus. Thus, this compound was tentatively identified as hesperidin, and further confirmed by comparing with reference compound [20]. Spectra of ion fragments in $\mathrm{MS}^{\mathrm{E}}$ analysis and the proposed fragmentation pattern of hesperidin in negative ion mode were shown in Figure 3.

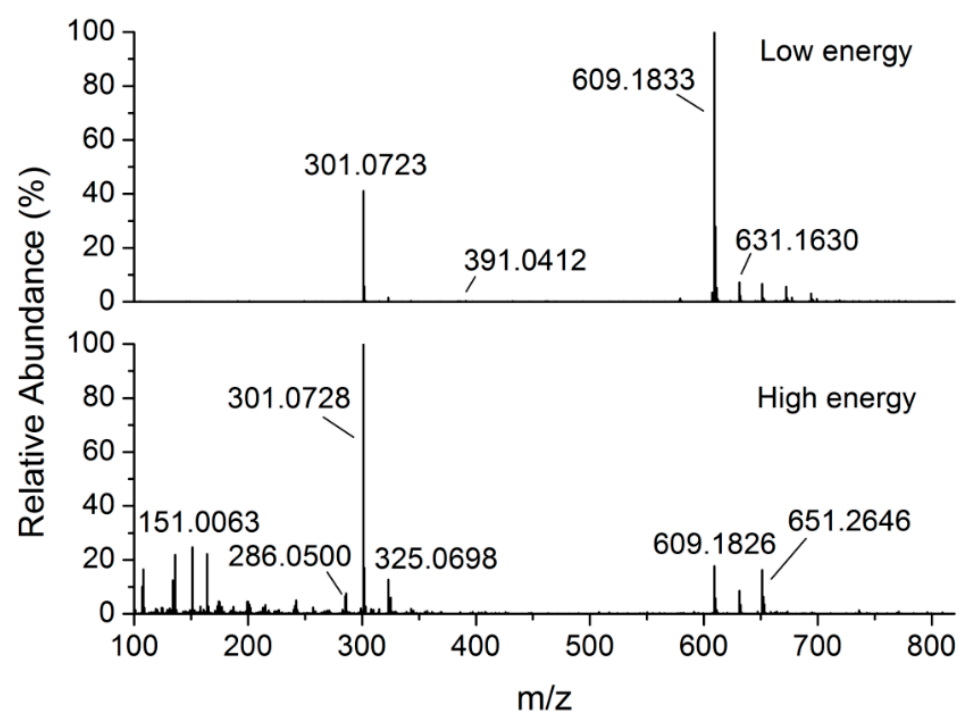

(a)

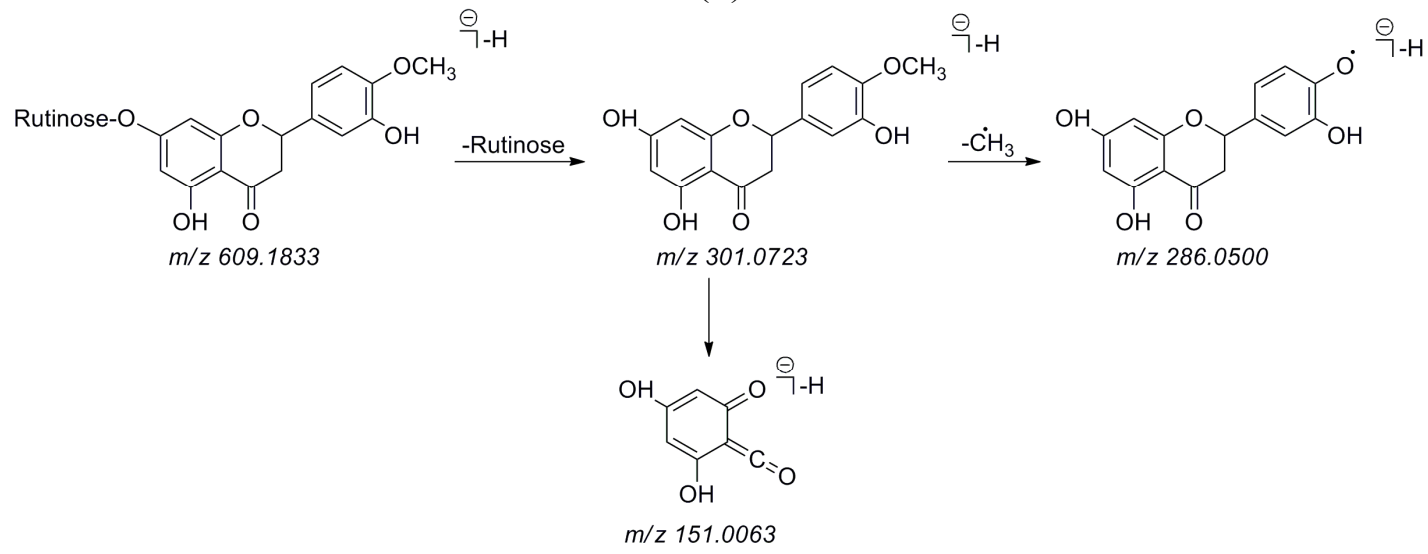

(b)

Figure 3. (a) ESI(-)-MS and $\mathrm{MS}^{\mathrm{E}}$ spectra of hesperidin (14); (b) ESI-MS/MS fragmentation pattern of hesperidin (14).

Three cyclic peptides (compounds 19, 26, and 29) were tentatively identified by analysis of their ESI(+)-MS spectra (Figures S1-S3 in the Supplementary Material) and compared with literature data [21,22]. For example, compound 19 had $[\mathrm{M}+\mathrm{Na}]^{+}$at $m / z 589.3329$, as well as $[\mathrm{M}+\mathrm{H}]^{+}$at $\mathrm{m} / \mathrm{z}$ 567.3504 , is indicative of the molecular formula as $\mathrm{C}_{27} \mathrm{H}_{46} \mathrm{~N}_{6} \mathrm{O}_{7}$. These data suggested that compound 19 was a cyclic peptide consisting of six amino acids. The ions at $m / z 454.2654,355.1535,242.1149$, and 185.0933 suggested the sequence of Leu, Val, Leu, and Gly. However, we did not find evidence for the connection of the other amino acids (Ser, Pro) in MS/MS spectrum. Thus, we tentatively identified compound 19 as cyclo(-Gly-Leu-Val-Leu-Pro-Ser-), which has been previously reported from Citrus aurantium [23]. Similiarly, compounds $\mathbf{2 6}$ and 29 were tentatively identified as citrusin I, and cyclo(-Gly-Gly-Leu-Leu-Leu-Pro-Pro-Phe-), respectively. 


\subsection{Effect of ZQ Aqueous Extract on Immobility Time in FST and TST}

The forced swimming test (FST) and tail suspension test (TST) are the most widely used animal models for antidepressant activity screening, partially because of their high predictive validity [24]. In the present study, oral administration of ZQ aqueous extract produced a marked reduction on immobility time in the FST $(p<0.05)$, similar to the positive control clomipramine hydrochloride. Furthermore, the significantly decrease on immobility time in the TST $(p<0.01)$ was also observed after treatment with the aqueous extract of ZQ. Both of the FST and TST experiments are suggestive of ZQ aqueous extract with significant antidepressant-like effect (Table 2 and Figure 4).

Table 2. Effect of ZQ on FST and TST in mice (mean \pm SD) $(n=10)$.

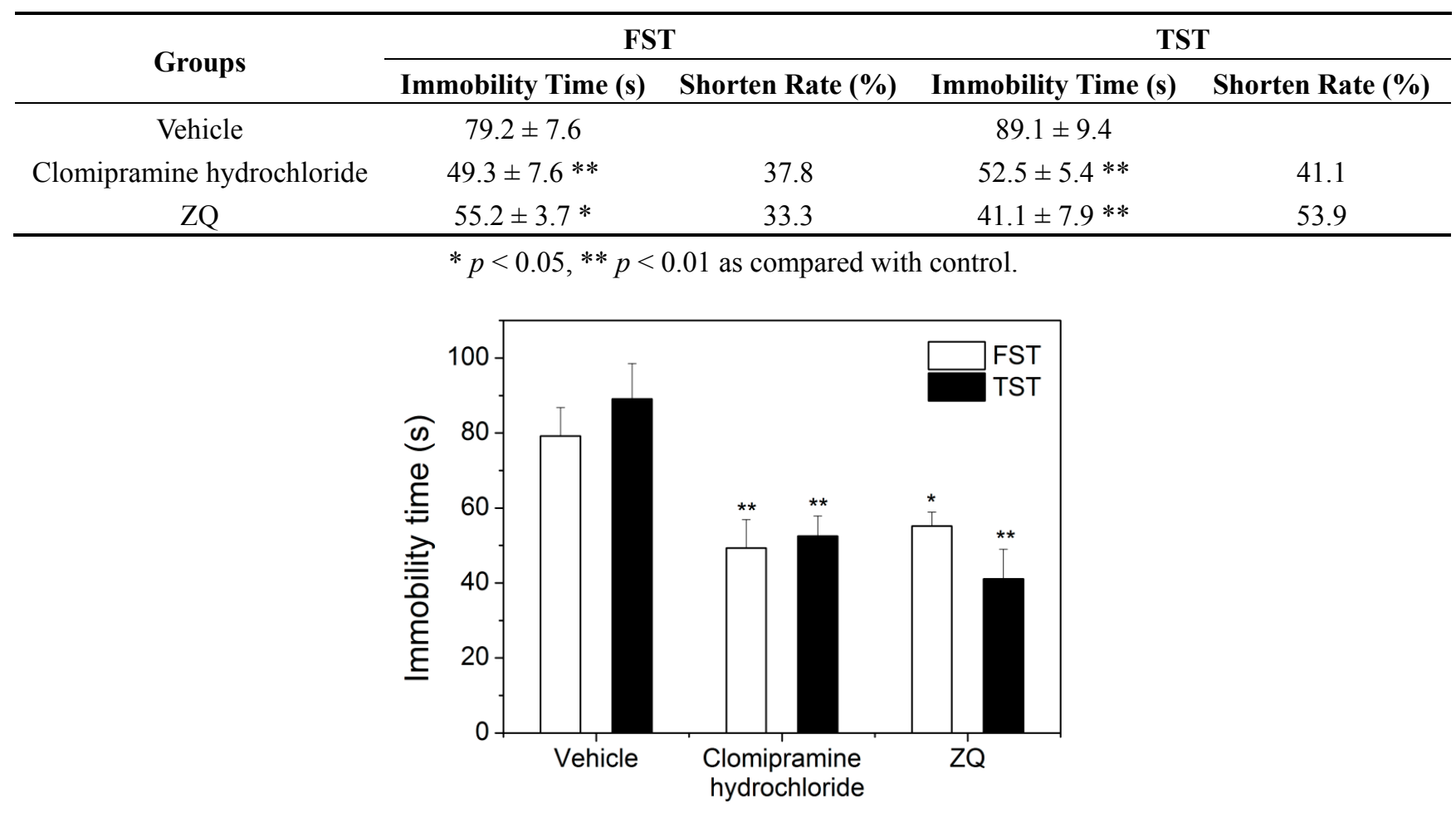

Figure 4. Effect of ZQ on FST and TST in mice (mean $\pm \mathrm{SD})(n=10) . * p<0.05, * * p<0.01$ as compared with vehicle.

\subsection{Neuroprotective Effect of ZQ Aqueous Extract on Corticosterone-Induced Neurotoxicity in PC12 Cells}

The PC12 cell line, derived from rat pheochromocytoma tumors, possesses typical neuron features and expresses a high level of glucocorticoid receptors. The PC12 cells treated with high concentration of glucocorticoid to induce the neuronal damage have been widely used as an in vitro experimental model of depression [25,26]. PC12 cells were treated with $200 \mu \mathrm{M}$ of corticosterone in the absence or presence of ZQ aqueous extract in varying concentrations for $48 \mathrm{~h}$. Then, cell viability was measured by MTT assay. The results showed that treatment with $200 \mu \mathrm{M}$ of corticosterone could induce cytotoxicity in PC12 cells. However, different concentrations of ZQ aqueous extract $(1,5,10,50$, and $100 \mathrm{mg} / \mathrm{L}$ ) significantly increased the cell viability, and the survival rates were $65.3 \%, 75.5 \%, 78.6 \%$, $73.9 \%$, and $69.6 \%$ of control, respectively (Figure 5). 


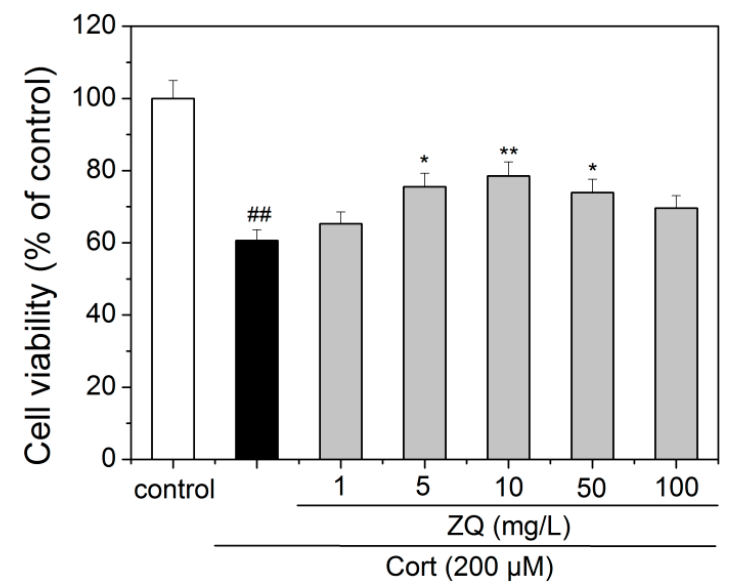

Figure 5. Effect of $Z Q$ on the cell viability in corticosterone-treated PC12 cells. The results are expressed as mean $\pm \mathrm{SD}(n=3) .{ }^{\#} p<0.01$ as compared with control group; $* p<0.05$ and $* * p<0.01$ as compared with the corticosterone group. ZQ: ZQ aqueous extract; Cort: corticosterone.

\subsection{Neuroprotective Effect of Four Major Components in ZQ Aqueous Extract on}

\section{Corticosterone-Induced Neurotoxicity in PC12 Cells}

The protection of four major components from ZQ aqueous extract against corticosterone-induced neurotoxicity in PC12 cells was also evaluated. When the cells were treated with naringin, hesperidin, neohesperidin, and nobiletin at $5,10,20 \mu \mathrm{M}$ in the presence of $200 \mu \mathrm{M}$ of corticosterone for $48 \mathrm{~h}$, the cell viability was significantly increased as compared with the corticosterone treated group (Figure 6).

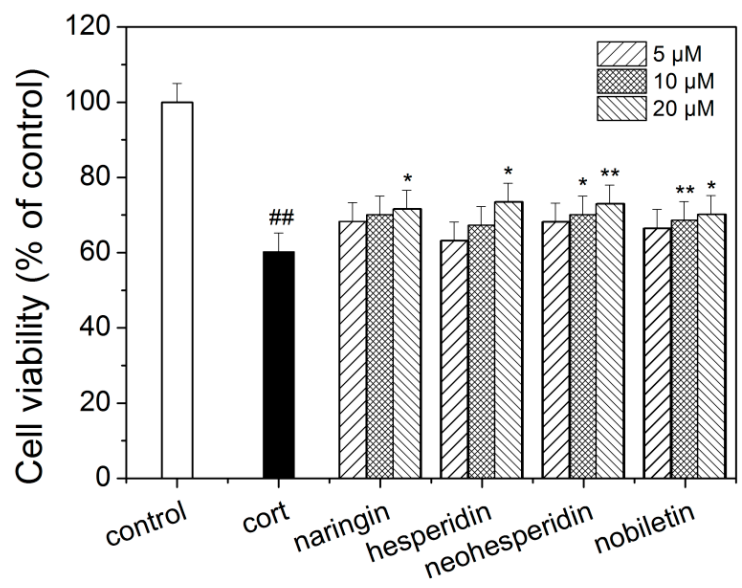

Figure 6. Effect of major components on the cell viability in corticosterone-treated PC12 cells. The results are expressed as mean $\pm \mathrm{SD}(n=3) .{ }^{\#} p<0.01$ as compared with control group; $* p<0.05$ and $* * p<0.01$ as compared with the corticosterone group. Cort: corticosterone.

\subsection{Discussion}

In present study, we identified 31 constituents in the ZQ extracts using UPLC-Q-TOF/MS and the antidepressant effect of ZQ aqueous extract had antidepressive-like effect in both the FST and TST assays in mice. In order to explore its mechanism of action, the neuroprotective effect of both ZQ 
aqueous extract and its four major constituents was evaluated on corticosterone-induced neurotoxicity in PC12 cells. Naringin, hesperidin, neohesperidin, and nobiletin had protection against corticosterone-induced neurotoxicity in PC12 cells in a dose-dependent manner. ZQ aqueous extract also showed protection at concentrations of 5 and $10 \mathrm{mg} / \mathrm{L}$, but had cytotoxicity at high concentrations $(50,100 \mathrm{mg} / \mathrm{L})$. The results indicated that neuroprotective effect of ZQ may be involved in antidepressant mechanism. Its major active constituents should be naringin, hesperidin, neohesperidin, and nobiletin. Obviously, there exist constituents with cytotoxicity on PC12 cells in ZQ aqueous extract.

Flavonoids are a large group of phenolic compounds that are widely distributed in plants, and are known to antidepressant-like activity at least in animal models of depression [27]. Many of flavonoids, such as rutin, quercetin and hesperidin, have a significant antidepressant effect in the FST [28]. It has been reported that the potential mechanism of hesperidin could be involved in modulation of the L-arginine-NO-cGMP pathway [29]. Nobiletin also has antidepressant-like effect in both the FST and TST in mice [30]. Our previous study reports that naringin, hesperidin, and neohesperidin show inhibition against monoamine oxidase (MAO) [19]. Thus, the antidepressant-like effect and the mechanism of action of those flavonoids from ZQ aqueous extract require further exploration.

\section{Experimental Section}

\subsection{Chemicals}

Reference substances of quinic acid, narirutin, naringin, hesperidin, neohesperidin, 3-methoxynobiletin, nobiletin, and tangeretin were purchased from the National Institute for the Control of Pharmaceutical and Biological Products (Beijing, China). All of the purities were above 98\% by HPLC analysis. Clomipramine hydrochloride tablets were purchased from Jiangsu En Pharmaceutical Co. Ltd. (Xuzhou, China). Dulbecco's Modified Eagle Medium (DMEM), fetal bovine serum, heat-inactivated horse serum, penicillin and streptomycin were purchased from Gibco (Grand Island, NY, USA). Corticosterone and MTT were purchased from Sigma-Aldrich (St. Louis, MO, USA). HPLC grade acetonitrile and methanol were purchased from Fisher (Waltham, MA, USA). Formic acid (HPLC grade) was purchased from Tedia (Fairfield, OH, USA). Water was prepared using a Millipore Milli-Q purification system (Bedford, MA, USA).

\subsection{Plant Material and Sample Preparation}

The raw herb was purchased from Beijing Tongren Tang Pharmaceutical Co. Ltd. (Beijing, China) and identified as the immature fruits of Citrus aurantium L. by Yulin Lin of the Institute of Medicinal Plant Development (IMPLAD), Chinese Academy of Medical Sciences and Peking Union Medical College. The voucher specimen is deposited in our laboratory of IMPLAD.

The raw herb was soaked in distilled water $(1: 10, w / v)$ for $0.5 \mathrm{~h}$ at room temperature and thereafter boiled for $1 \mathrm{~h}$. The filtrate was collected and the residue was then boiled again for $1 \mathrm{~h}$. The filtrates were combined, concentrated under vacuum and lyophilized to give extract. The yield of ZQ extract was $20.28 \%$. The accurately weighed ZQ extract $(0.5 \mathrm{~g})$ was dissolved in $25 \mathrm{~mL}$ of $50 \%$ methanol $(v / v)$, and centrifuged at $13,000 \mathrm{rpm}$ for $15 \mathrm{~min}$ at $4{ }^{\circ} \mathrm{C}$. The $2 \mu \mathrm{L}$ was injected for UPLC-Q-TOF/MS analysis after filtration through a $0.22 \mu \mathrm{m}$ membrane filter. All samples were analyzed in triplicate. 


\subsection{UPLC-Q-TOF/MS System}

The sample was analyzed on a Waters Acquity ${ }^{\mathrm{TM}}$ Ultra Performance LC system (Waters Corporation, Milford, MA, USA) equipped with an Acquity UPLC HSS T3 column $(100 \mathrm{~mm} \times 2.1 \mathrm{~mm}, 1.7 \mu \mathrm{m}$, Waters Corporation) at a column temperature of $35{ }^{\circ} \mathrm{C}$. The mobile phase was composed of water (A) and acetonitrile (B), each containing $0.1 \%$ formic acid. The line gradient program was carries out as follows: $10 \%-14 \% \mathrm{~B}$ at $0-2 \mathrm{~min} ; 14 \%-20 \% \mathrm{~B}$ at $2-6 \mathrm{~min} ; 20 \%-30 \% \mathrm{~B}$ at $6-9 \mathrm{~min} ; 30 \%-40 \% \mathrm{~B}$ at 9-11 min; $40 \%-70 \%$ B at $11-14 \mathrm{~min} ; 70 \%-99 \% \mathrm{~B}$ at $14-16 \mathrm{~min} ; 99 \% \mathrm{~B}$ at $16-18 \mathrm{~min}$; and $10 \% \mathrm{~B}$ at 18-20 min. The flow rate was $0.45 \mathrm{~mL} / \mathrm{min}$. The mass spectrometric data were collected using a Q-TOF analyzer in a SYNAPT HDMS system (Waters Corporation) in both positive and negative ion modes. The parameters were set as previously described [31]. The source temperature was set at $120{ }^{\circ} \mathrm{C}$ with a cone gas flow of $50 \mathrm{~L} / \mathrm{H}$, a desolvation gas temperature of $450{ }^{\circ} \mathrm{C}$ and a desolvation gas flow of $800 \mathrm{~L} / \mathrm{H}$. For the positive and negative ion modes, the capillary voltage was set to $3.0 \mathrm{kV}$ and $2.5 \mathrm{kV}$, respectively, and the cone voltage was set to $35 \mathrm{~V}$. Centroid data were collected from $\mathrm{m} / \mathrm{z} 50$ to 1200 with a scan time of $0.3 \mathrm{~s}$ and an interscan delay of $0.02 \mathrm{~s}$ over a $15 \mathrm{~min}$ analysis time. Leucine-enkephalin was used as the lock mass ( $\mathrm{m} / \mathrm{z} 556.2771$ in positive mode and $\mathrm{m} / \mathrm{z} 554.2615$ in negative mode) at a concentration of $0.5 \mu \mathrm{g} / \mathrm{mL}$ with a flow rate of $80 \mu \mathrm{L} / \mathrm{min}$. The lock spray frequency was set at $20 \mathrm{~s}$.

\subsection{Animals and Treatments}

Thirty male ICR mice, weighing 18-22 g were purchased from the Institute of Laboratory Animal Science, CAMS and PUMC (Beijing, China). The mice were housed individually in cages and maintained $\left(23 \pm 2{ }^{\circ} \mathrm{C}\right.$ and $40 \%-60 \%$ humidity) under a standard $12-\mathrm{h}$ light/dark cycle with free access to purified water and commercial diet. The mice were habituated for 7 days before the experiment. All experimental procedures were approved by the Ethics Committee of the Institute of Medicinal Plant Development, CAMS \& PUMC. The mice were randomly divided into three groups. The mice in the vehicle, positive control and ZQ treated groups were administrated with normal saline $(0.9 \% \mathrm{NaCl})$, clomipramine hydrochloride ( $40 \mathrm{mg} / \mathrm{kg}$ ) and ZQ (equivalent to $6 \mathrm{~g}$ crude drug/kg body weight), for 14 consecutive days, respectively.

\subsection{Forced Swimming Test Assay}

The forced swimming test was performed according to the conventional method of Porsolt [32]. Briefly, thirty minutes after the last drug administration, each mouse was forced to swim for 6 min in a glass cylinder $(20 \mathrm{~cm} \times 14 \mathrm{~cm})$ containing fresh water up to a height of $12 \mathrm{~cm}$ at $25 \pm 1{ }^{\circ} \mathrm{C}$. The duration of immobility was recorded for the last $4 \mathrm{~min}$ by two independent observers blinded to the treatments. All FSTs were recorded using a video camera.

\subsection{Tail Suspension Test Assay}

The tail suspension test was performed as previously described [33]. Briefly, thirty minutes after the last drug administration, mice were individually suspended by its tail using a clamp $(2 \mathrm{~cm}$ from the end) for $6 \mathrm{~min}$ in a box $(25 \times 25 \times 30 \mathrm{~cm})$ with the head $5 \mathrm{~cm}$ from the bottom. Testing was carried out in a darkened room with minimal background noise. The duration of immobility was recorded for the 
last 4 min by two independent observers blinded to the treatments. All TSTs were recorded using a video camera.

\subsection{Cell Culture and Treatment}

PC12 cells were obtained from the American Type Culture Collection (Rockville, MD, USA). PC12 cells were maintained in DMEM medium supplemented with penicillin $(100 \mathrm{U} / \mathrm{mL})$, streptomycin (100 $\mu \mathrm{g} / \mathrm{mL}$ ), $5 \%$ fetal bovine serum and $10 \%$ horse serum at $37{ }^{\circ} \mathrm{C}$ in humidified atmosphere of $95 \%$ air and $5 \% \mathrm{CO}_{2}$.

The appropriate damaging concentration of corticosterone was selected based on the results of Gao [34]. In brief, different concentrations of corticosterone $(10,50,100,200$, and $400 \mu \mathrm{M})$ were incubated with PC12 cells for $48 \mathrm{~h}$, and the cell viability was determined by MTT. When treated with $200 \mu \mathrm{M}$ corticosterone for $48 \mathrm{~h}$, the cell viability decreased to approximately $60 \%$, which induced cell injury without inducing cell death, and was used in subsequent experiments.

To research the neuroprotective effect of $Z Q$ and its major components, the experimental design contained the treatment groups as follows: non-treated control, $200 \mu \mathrm{M}$ of corticosterone, $200 \mu \mathrm{M}$ of corticosterone plus ZQ $(1,5,10,50$, and $100 \mathrm{mg} / \mathrm{L})$, and $200 \mu \mathrm{M}$ of corticosterone plus naringin, hesperidin, neohesperidin, and nobiletin $(5,10,20 \mu \mathrm{M})$. In the experiments, PC12 cells were seeded on a 96-well culture plates for $24 \mathrm{~h}$, then corticosterone was added $48 \mathrm{~h}$ prior to treatment with ZQ or its major components, and then the cells were co-incubated with corticosterone and ZQ or its major components for another $24 \mathrm{~h}$.

\subsection{Cell Viability Assay}

Cell survival was evaluated by 3-(4,5-dimethylthiazol-2-yl)-2,5-diphenyltetrazolium bromide (MTT) assay. Briefly, PC12 cells were seeded on a 96-well culture plates at a density of $1 \times 10^{5}$ cells/well. At the end of the treatment, the media was removed. Then the cells were washed with D-Hanks, and MTT solution (final concentration, $0.5 \mathrm{mg} / \mathrm{mL}$ ) was added and further incubated for $4 \mathrm{~h}$ at $37{ }^{\circ} \mathrm{C}$. Subsequently, the dark blue formazan crystals formed in intact cells were solubilized with DMSO. After shaking at room temperature for $10 \mathrm{~min}$, absorbance at $570 \mathrm{~nm}$ was measured with a microplate reader (Bio-Rad 550, Hercules, CA, USA). Cell viability was expressed as a percentage of the non-treated control.

\subsection{Statistical Analysis}

The results were presented as mean \pm standard deviation (SD). Data were analyzed using one-way analysis of variance (ANOVA) followed by post-hoc LSD test and differences were considered statistically significant at $p<0.05$. All experiments were performed in triplicate.

\section{Conclusions}

In the present study, an efficient and sensitive method employing ultra-performance liquid chromatography/time-of-flight mass spectrometry (UPLC-Q-TOF/MS) was developed for qualitative analysis of chemical constituents of ZQ aqueous extract. A total of 31 compounds including one tannic 
acid, five flavones, 13 flavanones, one limonoid, three coumarins, three cyclic peptides, and five polymethoxylated flavonoids were identified. The results from FST and TST indicated that ZQ aqueous extract owned antidepressant effect. Our results also showed that the protections of ZQ aqueous extract against corticosterone-induced neurotoxicity in PC12 cells. Four major components (naringin, hesperidin, neohesperidin, and nobiletin) displayed the protection against corticosterone-induced cytotoxicity in PC12 cells in a dose-dependent manner, a further clue they are main chemical constituents of ZQ responsible for its antidepressant effect [19].

\section{Supplementary Materials}

Supplementary materials can be accessed at: http://www.mdpi.com/1420-3049/20/04/6925/s1.

\section{Acknowledgments}

We gratefully acknowledge financial support from National Science and Technology Major Projects for "Major New Drugs Innovation and Development" (2012ZX09301002-001) and the National Natural Sciences Foundation of China (No. 81173512).

\section{Author Contributions}

Conceived of and designed the experiments: Z.Z.; Z.M. Performed the experiments: M.W.; H.Z.; C.Z.; H.J. Analyzed the data: M.W.; C.Z.; H.J. Contributed reagents/materials/analysis tools: H.Z.; H.J. Wrote the paper: Z.Z.; M.W. All authors read and approved the final manuscript.

\section{Conflicts of Interest}

The authors declare no conflict of interest.

\section{References}

1. Fugh-Berman, A.; Myers, A. Citrus aurantium, an ingredient of dietary supplements marketed for weight loss: Current status of clinical and basic research. Exp. Biol. Med. 2004, 229, 698-704.

2. Committee, N.P. Pharmacopoeia of the People's Republic of China; Chemical Industry Press: Beijing, China, 2005; pp. 171-172.

3. Gattuso, G.; Barreca, D.; Gargiulli, C.; Leuzzi, U.; Caristi, C. Flavonoid composition of citrus juices. Molecules 2007, 12, 1641-1673.

4. Haller, C.A.; Benowitz, N.L.; Jacob, P. Hemodynamic effects of ephedra-free weight-loss supplements in humans. Am. J. Med. 2005, 118, 998-1003.

5. Chen, H.; Zhang, W.; Yuan, J.; Li, Y.; Yang, S.; Yang, W. Simultaneous quantification of polymethoxylated flavones and coumarins in Fructus aurantii and Fructus aurantii immaturus using HPLC-ESI-MS/MS. J. Pharm. Biomed. 2012, 59, 90-95.

6. Steinmann, D.; Ganzera, M. Recent advances on HPLC/MS in medicinal plant analysis. J. Pharm. Biomed. 2011, 55, 744-757. 
7. Zhou, D.; Zhang, X.; Xu, Q.; Xue, X.; Zhang, F.; Liang, X. UPLC/Q-TOFMS/MS as a powerful technique for rapid identification of polymethoxylated flavones in Fructus aurantii. J. Pharm. Biomed. 2009, 50, 2-8.

8. Zhou, D.; Chen, D.; Xu, Q.; Xue, X.; Zhang, F.; Liang, X. Characterization of polymethoxylated flavones in Fructus aurantii by liquid chromatography with atmospheric pressure chemical ionization combined with tandem mass spectrometry. J. Pharm. Biomed. 2007, 43, 1692-1699.

9. Lin, Z.; Wang, H.; Xu, Y.; Dong, J.; Hashi, Y.; Chen, S. Identification of antioxidants in Fructus aurantii and its quality evaluation using a new on-line combination of analytical techniques. Food Chem. 2012, 134, 1181-1191.

10. Sakata, K.; Hirose, Y.; Qiao, Z.; Tanaka, T.; Mori, H. Inhibition of inducible isoforms of cyclooxygenase and nitric oxide synthase by flavonoid hesperidin in mouse macrophage cell line. Cancer Lett. 2003, 199, 139-145.

11. Wang, Q.H.; Shu, Z.P.; Xu, B.Q.; Xing, N.; Jiao, W.J.; Yang, B.Y.; Kuang, H.X. Structural characterization and antioxidant activities of polysaccharides from Citrus aurantium L. Int. J. Biol. Macromol. 2014, 67, 112-123.

12. Garg, A.; Garg, S.; Zaneveld, L.; Singla, A.K. Chemistry and pharmacology of the Citrus bioflavonoid hesperidin. Phytother. Res. 2001, 15, 655-669.

13. Wu, Y.Q.; Zhou, C.H.; Tao, J.; Li, S.N. Antagonistic effects of nobiletin, a polymethoxyflavonoid, on eosinophilic airway inflammation of asthmatic rats and relevant mechanisms. Life Sci. 2006, $78,2689-2696$.

14. Jayaprakasha, G.K.; Negi, P.S.; Sikder, S.; Mohanrao, L.J.; Sakariah, K.K. Antibacterial activity of Citrus reticulata peel extracts. Z. Naturforsch. C 2000, 55, 1030-1034.

15. Kobayashi, S.; Tanabe, S. Evaluation of the anti-allergic activity of Citrus unshiu using rat basophilic leukemia RBL-2H3 cells as well as basophils of patients with seasonal allergic rhinitis to pollen. Int. J. Mol. Med. 2006, 17, 511-515.

16. Li, R.W.; Theriault, A.G.; Au, K.; Douglas, T.D.; Casaschi, A.; Kurowska, E.M.; Mukherjee, R. Citrus polymethoxylated flavones improve lipid and glucose homeostasis and modulate adipocylokines in fructose-induced insulin resistant hamsters. Life Sci. 2006, 79, 365-373.

17. Xu, Y.; Feng, J. Mechanism underlying the antidepressant effect of Fructus aurantii. Chin. J. Pharmacol. Ther. 2013, 1086-1092.

18. Zhang, H.; Zou, Z. Application in clinic and research advances of ChaiHu-Shu-Gan-San. Lishizhen Med. Mater. Med. Res. 2007, 1234-1236.

19. Jia, H.; Su, Z.; Long, W.; Liu, Y.; Chang, X.; Zhang, H.; Ding, G.; Feng, Y.; Cai, D.; Zou, Z. Metabonomics Combined with UPLC-MS Chemical Profile for Discovery of Antidepressant Ingredients of a Traditional Chinese Medicines Formula, Chaihu-Shu-Gan-San. Evid. Based Complement. Altern. Med. 2013, 2013, 487158, doi:10.1155/2013/487158.

20. Wang, C.; Pan, Y.; Fan, G.; Chai, Y.; Wu, Y. Application of an efficient strategy based on MAE, HPLC-DAD-MS/MS and HSCCC for the rapid extraction, identification, separation and purification of flavonoids from Fructus Aurantii Immaturus. Biomed. Chromatogr. 2010, 24, 235-244.

21. Matsubara, Y. Structures of New Cyclic Peptides in Young Unshiu (Citrus unshiu Marcov.), Orange (Citrus sinensis Osbeck.) Peelings. Agric. Biol. Chem. 1991, 55, 2923-2929. 
22. Matsumoto, T.; Tashiro, N.; Nishimura, K.; Takeya, K. New cyclic peptides from Citrus aurantium. Heterocycles 2002, 57, 477-482.

23. Peng, W.; Tan, N. Cyclopeptides from Immature Fruits of Citrus aurantium. Nat. Prod. Res. Dev. 2014, 26, 1416-1420.

24. Peng, W.; Lo, K.; Lee, Y.; Hung, T.; Lin, Y. Berberine produces antidepressant-like effects in the forced swim test and in the tail suspension test in mice. Life Sci. 2007, 81, 933-938.

25. Zhu, M.Y.; Wang, W.P.; Bissette, G. Neuroprotective effects of agmatine against cell damage caused by glucocorticoids in cultures rat hippocampal neurons. Neuroscience 2006, 141, 2019-2027.

26. Mao, Q.; Huang, Z.; Ip, S.; Xian, Y.; Che, C. Protective Effects of Piperine Against Corticosterone-Induced Neurotoxicity in PC12 Cells. Cell. Mol. Neurobiol. 2012, 32, 531-537.

27. Pathak, L.; Agrawal, Y.; Dhir, A. Natural polyphenols in the management of major depression. Expert Opin. Investig. Drugs 2013, 22, 863-880.

28. Herrera-Ruiz, M.; Zamilpa, A.; Gonzalez-Cortazar, M.; Reyes-Chilpa, R.; Leon, E.; Garcia, M.P.; Tortoriello, J.; Huerta-Reyes, M. Antidepressant effect and pharmacological evaluation of standardized extract of flavonoids from Byrsonima crassifolia. Phytomedicine 2011, 18, 1255-1261.

29. Donato, F.; de Gomes, M.G.; Goes, A.; Borges, C.; Del Fabbro, L.; Antunes, M.S.; Souza, L.C.; Boeira, S.P.; Jesse, C.R. Hesperidin exerts antidepressant-like effects in acute and chronic treatments in mice: Possible role of L-arginine-NO-cGMP pathway and BDNF levels. Brain Res. Bull. 2014, 104, 19-26.

30. Yi, L.T.; Xu, H.L.; Feng, J.; Zhan, X.; Zhou, L.P.; Cui, C.C. Involvement of monoaminergic systems in the antidepressant-like effect of nobiletin. Physiol. Behav. 2011, 102, 1-6.

31. Su, Z.; Li, S.; Zou, G.; Yu, C.; Sun, Y.; Zhang, H.; Gu, Y.; Zou, Z. Urinary metabonomics study of anti-depressive effect of Chaihu-Shu-Gan-San on an experimental model of depression induced by chronic variable stress in rats. J. Pharm. Biomed. 2011, 55, 533-539.

32. Porsolt, R.D.; Bertin, A.; Jalfre, M. Behavioral despair in mice: A primary screening test for antidepressants. Arch. Int. Pharmacodyn. Ther. 1977, 229, 327-336.

33. Steru, L.; Chermat, R.; Thierry, B.; Simon, P. The tail suspension test: A new method for screening antidepressants in mice. Psychopharmacology 1985, 85, 367-370.

34. Gao, M.; Zhou, H.; Li, X. Curcumin Protects PC12 Cells from Corticosterone-Induced Cytotoxicity: Possible Involvement of the ERK1/2 Pathway. Basic Clin. Pharmacol. 2009, 104, 236-240.

Sample Availability: Samples of Zhi-Qiao are available from the authors.

(C) 2015 by the authors; licensee MDPI, Basel, Switzerland. This article is an open access article distributed under the terms and conditions of the Creative Commons Attribution license (http://creativecommons.org/licenses/by/4.0/). 